\title{
A NEW NI-BASE SUPERALLOY FOR OIL AND GAS APPLICATIONS
}

\author{
Sarwan Mannan and Shailesh Patel \\ Special Metals Corporations, Huntington, WV 25705-1771
}

Key words: 945, Chemistry, Corrosion, oil and gas, microstructure

\begin{abstract}
A new Ni-base precipitation strengthened alloy has been developed to provide $860 \mathrm{MPa}$ minimum yield strength and an excellent combination of ductility and impact strength. Testing in various corrosive environments has shown that the alloy has excellent stress corrosion and sulfide stress corrosion resistance. A number of commercial heats were melted and processed to establish robust mill processing practice. This paper will talk about the overall alloy development methodology including heat treatment studies to optimize microstructure and target mechanical and corrosion properties to obtain the most cost effective solution to the needs of the oil and gas $(O \& G)$ industry.
\end{abstract}

\section{Introduction}

As older shallow and less corrosive O\&G wells deplete, higher strength and more corrosion resistant materials are needed to enable deeper drilling into more corrosive environments. The commonly used Ni-base superalloys 718 and 925 do not always offer an adequate combination of strength and corrosion resistance hence the need to develop a new alloy.

Material selection is especially critical for sour gas wells -- those containing $\mathrm{H}_{2} \mathrm{~S}[1,2]$. These wells operate at a high temperature of up to $232^{\circ} \mathrm{C}$ and may also contain free sulfur. Additionally, these wells generally contain high levels of chlorides and $\mathrm{CO}_{2}$. Combinations of this type of corrosive media require special care when designing an alloy.

Nominal composition of newly developed alloy 945 is Fe-47Ni20.5Cr-3Mo-2Cu-3Nb-1.5Ti. The relative concentrations of Fe$\mathrm{Ni}-\mathrm{Cr}-\mathrm{Mo}-\mathrm{Cu}$ determine overall corrosion resistance in O\&G applications. A minimum of $42 \mathrm{Ni}$ is needed for aqueous stress corrosion cracking [3]. Molybdenum is beneficial for pitting corrosion resistant in reducing acids and alkalies [4]. Chromium improves general corrosion resistance and corrosion resistance in oxidizing media [4]. High concentrations of Mo and $\mathrm{Cr}$ lead to structural instability [5]. Copper is found to be beneficial for general corrosion in non-oxidizing corrosion environments. A synergistic affect of $\mathrm{Cu}$ and $\mathrm{Mo}$ is recognized for countering corrosion in reducing acidic environments which are rich in chlorides [6]. Nb, $\mathrm{Ti}$, and $\mathrm{Al}$ are of course added for precipitation strengthening [7].

Data in the literature shows that alloy 925 has superior corrosion resistance to alloy 718 in certain oil patch environments [8]. However, the yield strength capability of alloy 925 is lower than alloy 718 [9]. The aim of the project was to develop a cost effective hybrid of alloys 925 and 718, which has best of both the alloys -- higher strength capability and excellent corrosion resistance.

\section{Laboratory Alloy Development}

The initial development phase consisted of vacuum induction melting $22 \mathrm{Kg}$ lab heats. These heats were homogenized, hotrolled, and subjected to annealing and aging studies. First phase of evaluation of laboratory heats was done based on microstructure and hardness of annealed plus aged material. The heats that showed potential were tested for tensile, impact, hardness, and microstructure. To begin with, a thermodynamics based software, JMatPro [10], was used to simulate some of the potential chemical compositions. This software predicts variation of strength with chemical composition. However, it does not give any guidance for inter-granular microstructure. Over 100 lab heats were evaluated in this program. Table 1 shows selected lab heats listed to illustrate the observed trends.

\section{Effect of Ti}

Ti in alloy 925 composition was varied from 2.5 to $3.4 \mathrm{wt} \%$ as shown in heats S2-A to S2-C in Table 1. An increase in Ti showed a lot of potential to strengthen the alloys. A plot of hardness versus Ti content is shown in Figure 1. The hardness increased rapidly as Ti content was increased. However, increase in Ti also degraded microstructural stability. Cellular inter-granular Eta phase colonies were observed on age hardening, Figure 2. Based on the limited data reported in the literature, any inter-granular second phase precipitation is likely to degrade corrosion resistance in O\&G applications [9]. 
Table 1. Chemical compositions of the lab heats

\begin{tabular}{|c|c|c|c|c|c|c|c|c|c|}
\hline Alloy & $\mathrm{Fe}$ & $\mathrm{Ni}$ & $\mathrm{Cr}$ & $\mathrm{Mo}$ & $\mathrm{Cu}$ & $\mathrm{C}$ & $\mathrm{Al}$ & $\mathrm{Nb}$ & $\mathrm{Ti}$ \\
\hline $\begin{array}{c}\text { Alloy } \\
\text { 925 }\end{array}$ & $\mathrm{Bal}$ & 42.3 & 20.3 & 3.2 & 2.0 & 0.014 & 0.2 & 0.3 & 2.3 \\
\hline $\begin{array}{c}\text { Alloy } \\
718\end{array}$ & Bal & 54 & 18.5 & 3.2 & - & 0.015 & 0.5 & 5.0 & 1.0 \\
\hline & & & & & & & & & \\
\hline S2-A & Bal & 42.5 & 20.6 & 3.4 & 1.7 & 0.013 & 0.4 & 0.3 & $\mathbf{2 . 5}$ \\
\hline S2-B & Bal & 42.5 & 20.8 & 3.4 & 2.1 & 0.015 & 0.4 & 0.3 & $\mathbf{3 . 0}$ \\
\hline S2-C & Bal & 42.8 & 20.4 & 3.4 & 1.8 & 0.021 & 0.4 & 0.3 & $\mathbf{3 . 4}$ \\
\hline & & & & & & & & & \\
\hline S3-A & Bal & $\mathbf{4 5 . 0}$ & 20.6 & 3.2 & 2.0 & 0.006 & $\mathbf{0 . 6}$ & 0.3 & 2.3 \\
\hline S3-B & Bal & $\mathbf{4 8 . 0}$ & 20.5 & 3.2 & 2.0 & 0.005 & $\mathbf{1 . 2}$ & 0.3 & 2.3 \\
\hline & & & & & & & & & \\
\hline S4-A & Bal & $\mathbf{4 5 . 5}$ & 20.5 & 3.3 & 2.0 & 0.009 & $\mathbf{1 . 0}$ & $\mathbf{1 . 0}$ & 2.3 \\
\hline S4-B & Bal & $\mathbf{4 8 . 8}$ & 20.5 & 3.3 & 2.1 & 0.008 & $\mathbf{1 . 0}$ & $\mathbf{1 . 0}$ & 2.3 \\
\hline
\end{tabular}

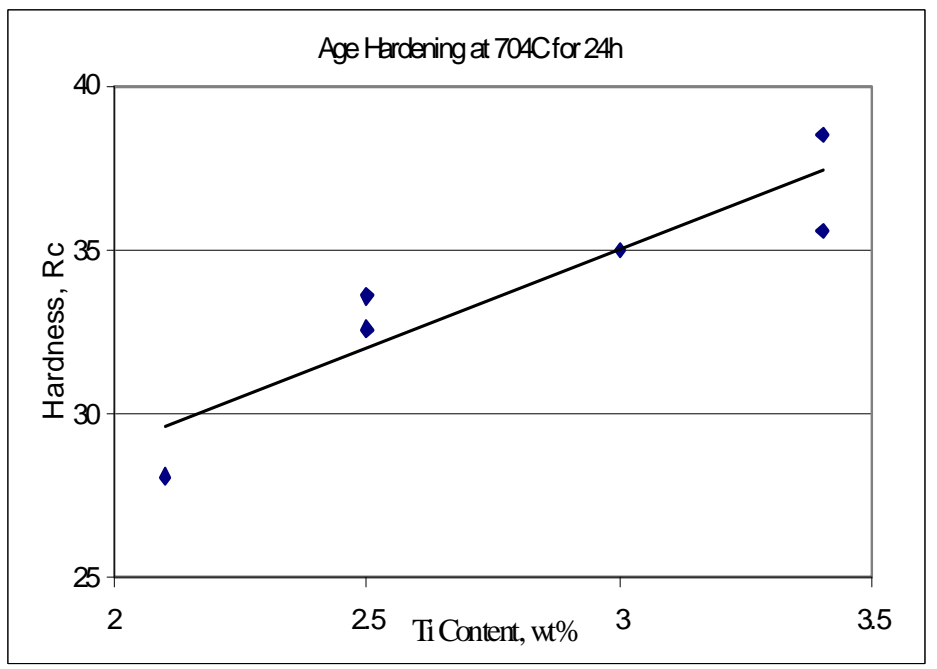

Figure 1. Hardness versus Ti content of S2 series of alloys.

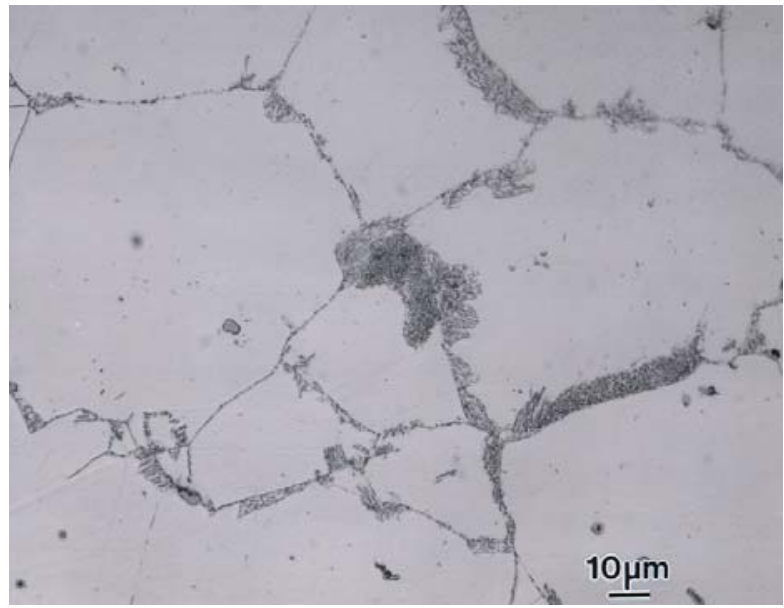

Figure 2. Optical photograph of annealed plus aged S2-C alloy containing 3.4Ti.

\section{$\underline{\text { Effect of Al }}$}

Aluminum in the base alloy 925 composition was varied from 0.3 to $1.2 \mathrm{wt} \%$ in S3 heats as shown in Table 1. Interestingly, an increase in $\mathrm{Al}$ from 0.3 to 0.6 decreased hardness, Figure 3. However, with $1.2 \mathrm{Al}$, the hardness was equivalent to that of $0.3 \mathrm{Al}$. The lower hardness of $1.2 \mathrm{Al}$ alloy as compared to $0.6 \mathrm{Al}$ alloy in the plot for 24 hours exposure is probably due to overaging. An increase in $\mathrm{Al}$ increases the volume fraction of gamma prime [7], which increases hardness. Further, an increase in $\mathrm{Al}$ is also thought to decreases the lattice mismatch / coherency strain [7], which decreases hardness. The observed variations in hardness with $\mathrm{Al}$ are combined effects of these two factors. An addition of 1.2Al led to higher inter-granular carbide precipitation, which is detrimental for O\&G type aqueous corrosion applications [9]. Based on this data, higher additions than $1.2 \mathrm{Al}$ were not studied.

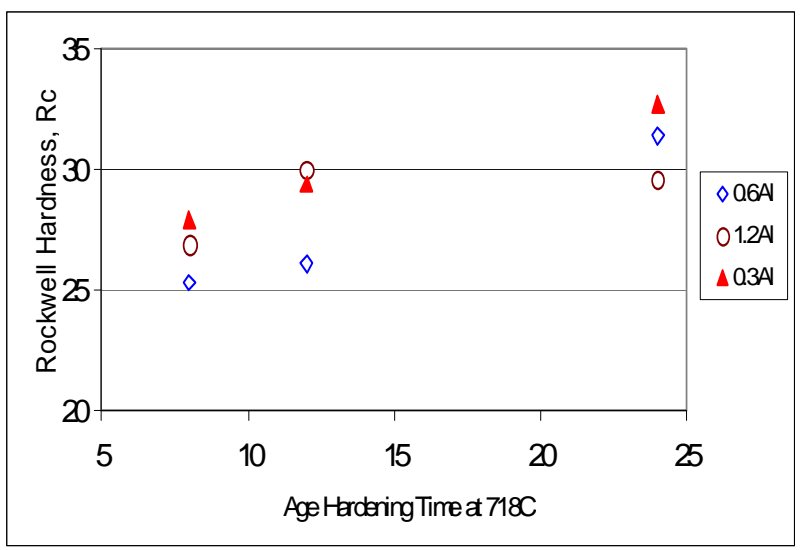

Figure 3. Hardness versus age hardening time at $718^{\circ} \mathrm{C}$ for S3 alloys. 


\section{Relationship between $\mathrm{Nb}$ and $\mathrm{Al}$}

Increase in both $\mathrm{Al}$ and $\mathrm{Nb}$ in alloy 925 increased hardness but marginally decreased yield strength as shown for S4 heats in Table 1 and 2. This is contrary to JMatPro simulations, which suggest an increase in yield strength with this combination of hardeners, Table 2. An increase in hardness but a decrease in yield strength can be misleading because hardness values are typically used as an initial screen during alloys development. Increase in hardness in this set of heats did however increase tensile strength, which is consistent with reported literature, where hardness is correlated to the tensile strength for steel, [11]. These results indicated that increasing $\mathrm{Al}$ beyond the levels in alloy 925 would not be beneficial in the new alloy.

\section{Relationship between $\mathrm{Nb}$ and $\mathrm{Ti}$}

Once the behavior and optimum level of $\mathrm{Al}$ was determined in the alloy, the synergies between $\mathrm{Nb}$ and $\mathrm{Ti}$ were studied. JMatPro showed that an increase in $\mathrm{Nb}$ together with a decrease in $\mathrm{Ti}$ in alloy 925 is required to increase strength, Figure 4 . Based on this information, a number of lab heats were prepared to study the $\mathrm{Nb}$ / Ti effect. The experimental results on yield strength were consistent with JMatPro simulations. Further, these synergistic variations in $\mathrm{Nb}$ and $\mathrm{Ti}$ resulted in a microstructure, which was essentially devoid of any inter-granular precipitation. A number of lab heats were evaluated for further processing and properties to optimize the final chemical composition of alloy 945 listed in Table 3.

Table 2. Room temperature yield strength of annealed plus two-step aged S4 heats. YS, UTS, EL, and RA stand for yield strength, tensile strength, elongation, and reduction-of-area respectively.

\begin{tabular}{|c|c|c|c|c|c|c|}
\hline Alloy & Hardness, Rc & $\begin{array}{c}\text { JMatPro predicted } \\
\text { YS, ksi }\end{array}$ & YS, ksi & UTS, ksi & \% El RA & \% RA \\
\hline 925 & 34 & 82 & 118 & 173 & 23 & 27 \\
\hline S4-A & 38 & 96 & 112 & 183 & 25 & 25 \\
\hline S4-B & 38 & 99 & 109 & 180 & 26 & 39 \\
\hline
\end{tabular}

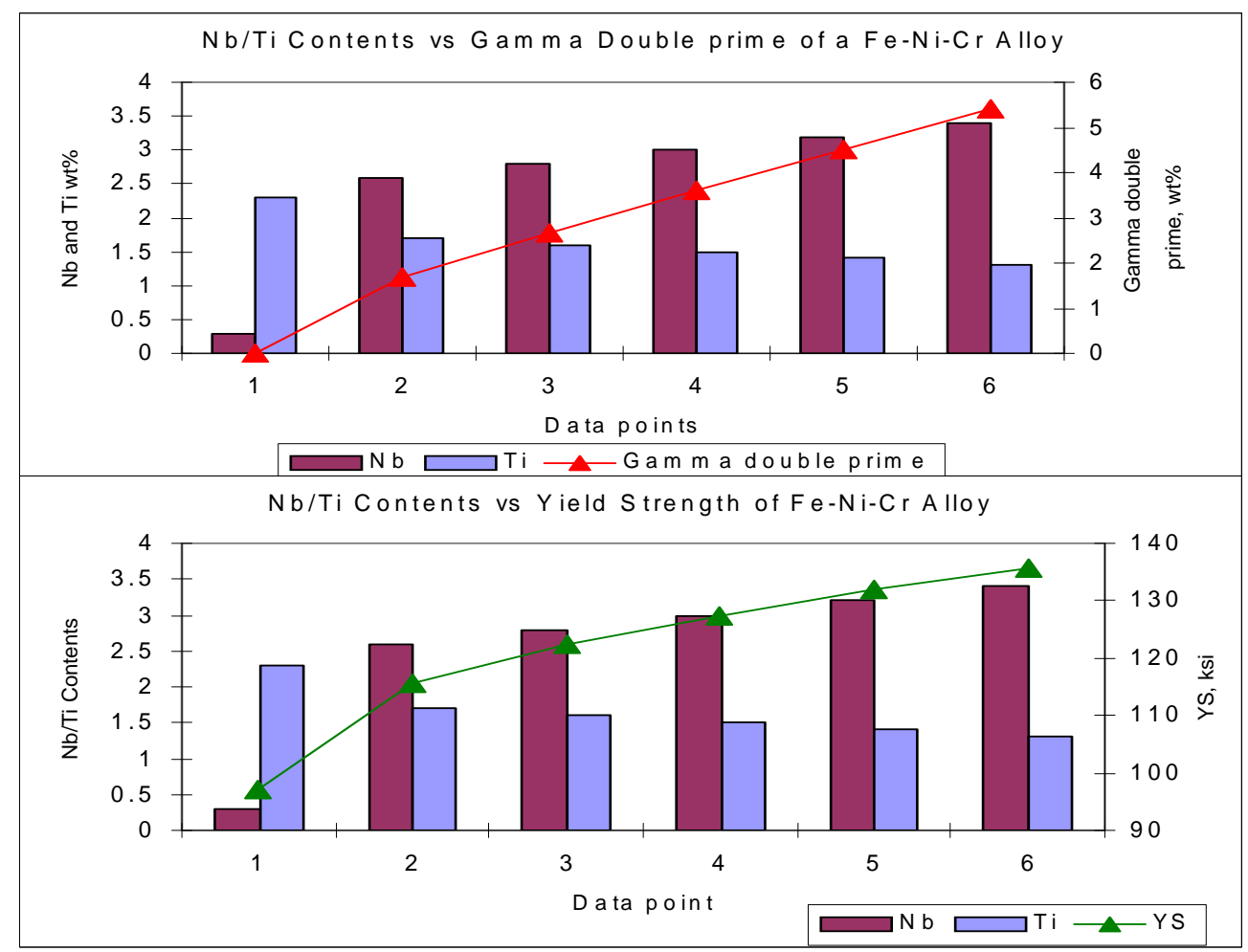

Figure 4. JMatPro simulations showing synergistic increase in $\mathrm{Nb}$ and decrease in Ti result in increase in Gamma double prime (upper plot) and increase in yield strength (lower plot). 
Table 3. Nominal chemical compositions 925, 945, and 718.

\begin{tabular}{|c|c|c|c|c|c|c|c|c|c|}
\hline Alloy & Fe & $\mathrm{Ni}$ & $\mathrm{Cr}$ & $\mathrm{Mo}$ & $\mathrm{Cu}$ & $\mathrm{C}$ & $\mathrm{Al}$ & $\mathrm{Nb}$ & $\mathrm{Ti}$ \\
\hline 925 & Bal & 42.3 & 20.3 & 3.2 & 2.0 & 0.014 & 0.2 & 0.3 & 2.3 \\
\hline 945 & Bal & $\mathbf{4 7}$ & $\mathbf{2 0 . 5}$ & $\mathbf{3 . 3}$ & $\mathbf{2 . 0}$ & $\mathbf{0 . 0 1 0}$ & $\mathbf{0 . 2}$ & $\mathbf{3 . 0}$ & $\mathbf{1 . 5}$ \\
\hline 718 & Bal & 54 & 18.5 & 3.2 & - & 0.015 & 0.5 & 5.0 & 1.0 \\
\hline
\end{tabular}

\section{Results and Discussion on Mill Scale Heats}

\section{Processing}

An optimized composition of alloy 945 was melted and re-melted in the mill as three commercial heats weighing 22000 to 32,000 $\mathrm{kg}$ each. Although a number of variations in electrode / ingots sizes were evaluated, the most common sizes used were $457 \mathrm{~mm}$ electrode re-melting to $508 \mathrm{~mm}$ ingot. Melting processes evaluated were vacuum induction melting (VIM) and electric arc furnace $(\mathrm{EAF})+$ argon oxygen decarburization (AOD). The melted electrodes were re-melted using vacuum arc re-melting (VAR) and electroslag re-melting (ESR). The alloy has proved to be process friendly to all the various combinations of primary and secondary melt methods.

Figure 5 shows a $508 \mathrm{~mm}$ VIM +VAR ingot. The ingots produced by various melt methods were rolled or forged to round bars. Figure 6 shows a 229mm diameter forged bar weighing 2300Kg. Hot rolled bars were annealed at $1038^{\circ} \mathrm{C}$ for times according to the section sizes and water quenched. Then, the material was two step aged as follows: $718^{\circ} \mathrm{C} / 8 \mathrm{~h}$, furnace cool at $56^{\circ} \mathrm{C} / \mathrm{h}$ to $621^{\circ} \mathrm{C}$, hold at $621^{\circ} \mathrm{C} / 8 \mathrm{~h}$, air cool.

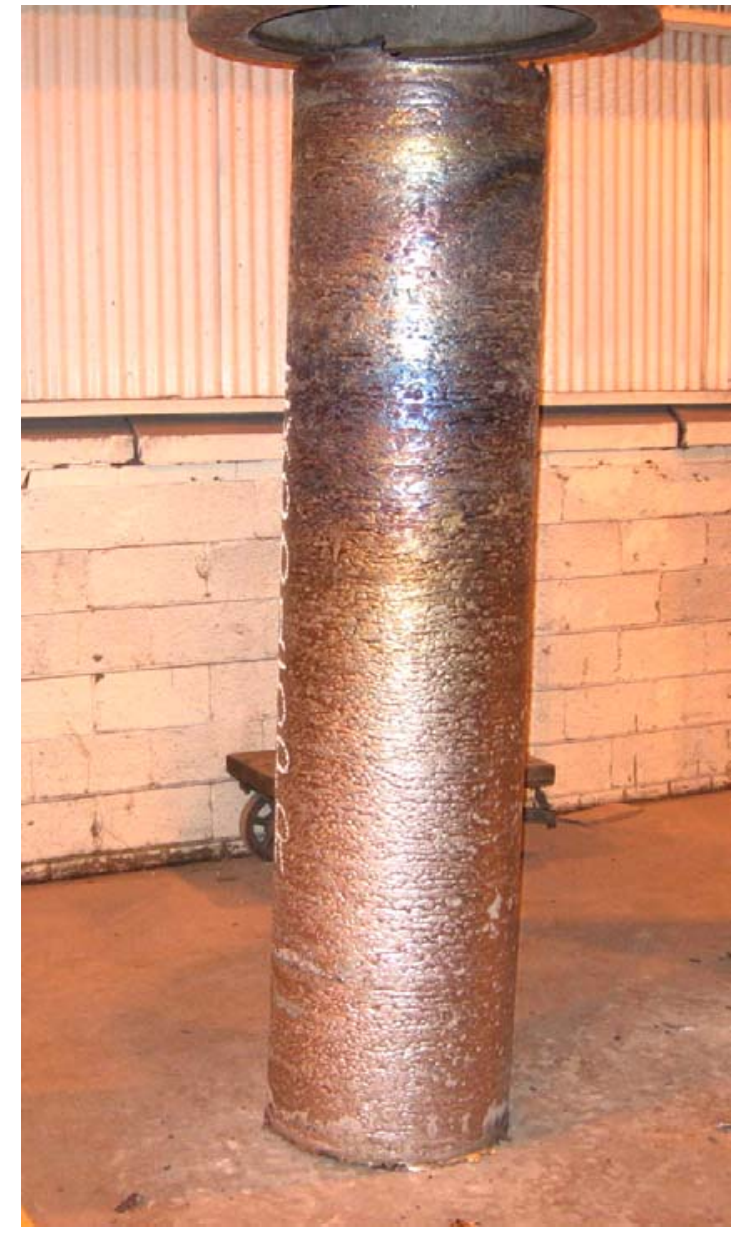

Figure 5. VIM + VAR ingot of 508mm diameter. 


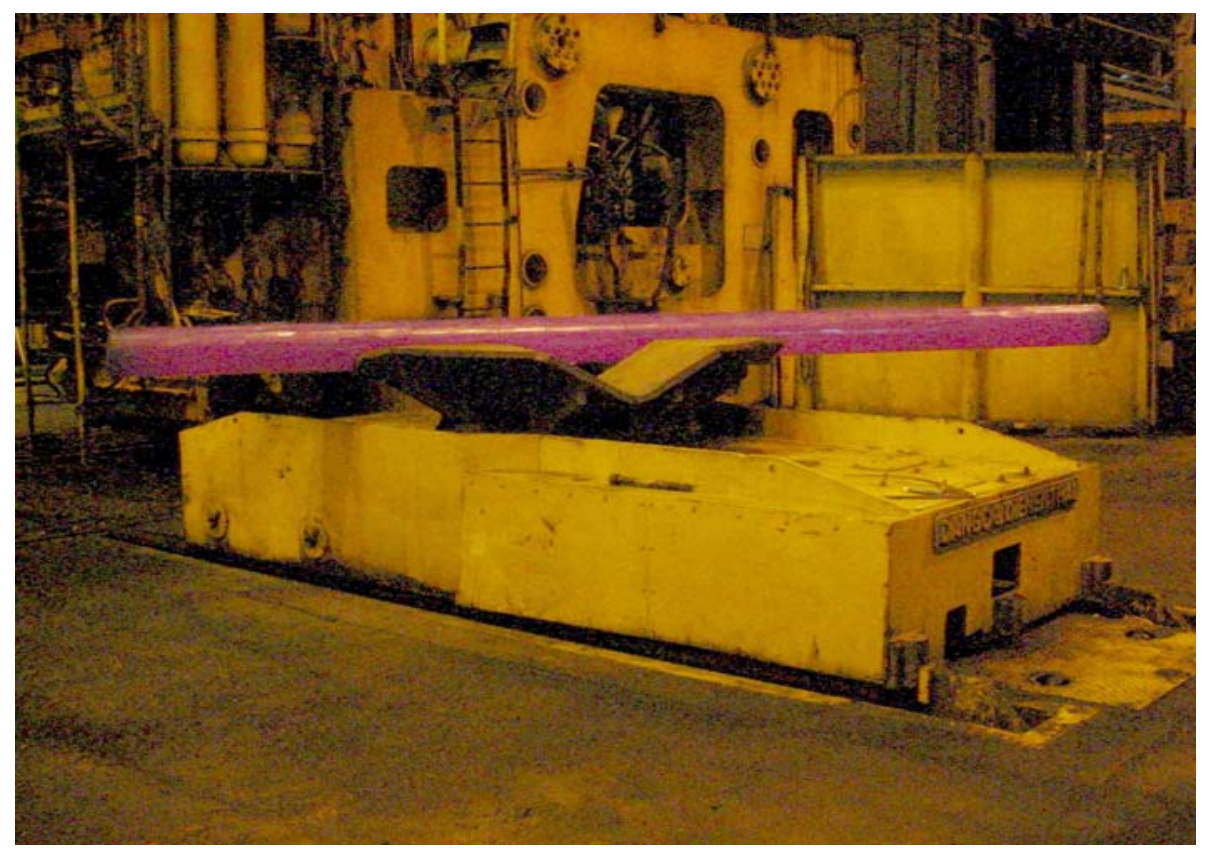

Figure 6. A forged bar of 229mm diameter weighing 2300kg.

\section{$\underline{\text { Mechanical Properties }}$}

Rod sizes of diameter ranging from $25 \mathrm{~mm}$ to $356 \mathrm{~mm}$ were produced and tested for room temperature tensile, grain size, hardness, and Charpy impact testing. The impact testing was conducted at $-23^{\circ} \mathrm{C}$. Impact tests for rod diameters $76 \mathrm{~mm}$ or less were conducted in the longitudinal orientation, whereas for over $76 \mathrm{~mm}$, the tests were conducted in the transverse orientation.
All the tensile testing was done in the longitudinal orientation. Table 4 shows the mechanical properties. The impact values listed are the averages of 3 tests. Being the first scale up heats for the alloy, multiple testing was conducted at extreme ends of a bar or on different bars produced in a lot to ensure uniformity in the material. The listed multiple values for selected sizes represent data generated in this way. The alloy clearly met the target mechanical properties.

Table 4. Mechanical properties of annealed + aged alloy 945. YS, UTS, EL, and RA stand for yield strength, tensile strength, elongation, and reduction-of-area respectively.

\begin{tabular}{|c|c|c|c|c|c|c|c|}
\hline $\begin{array}{c}\text { Rod Size, } \\
\text { mm }\end{array}$ & $\mathrm{YS}, \mathrm{MPa}$ & UTS, MPa & \% El & \% RA & $\begin{array}{c}\text { Impact, } \\
\text { Joules }\end{array}$ & Hardness, Rc & $\begin{array}{c}\text { Grain Size, } \\
\text { ASTM \# }\end{array}$ \\
\hline \multirow[t]{2}{*}{25} & 919.8 & 1194.2 & 27.8 & 48.0 & 103 & 40 & 2 \\
\hline & 939.1 & 1205.2 & 26.1 & 46.1 & 85 & 40 & 3 \\
\hline \multirow[t]{2}{*}{51} & 913.6 & 1173.5 & 28.2 & 47.6 & 95 & 40 & 3 \\
\hline & 942.5 & 1201.8 & 25.7 & 40.1 & 75 & 40 & 3 \\
\hline \multirow[t]{2}{*}{89} & 939.8 & 1201.1 & 24.9 & 39.5 & 77 & 40 & 2 \\
\hline & 934.3 & 1185.9 & 25.5 & 40.5 & 79 & 43 & 2 \\
\hline \multirow[t]{2}{*}{114} & 925.3 & 1162.5 & 28.6 & 46.7 & 84 & 42 & 2.5 \\
\hline & 929.5 & 1171.5 & 26.6 & 45.6 & 84 & 39 & 2 \\
\hline \multirow[t]{2}{*}{152} & 957.0 & 1183.9 & 23.7 & 35.9 & 92 & 40 & 2 \\
\hline & 972.2 & 1213.5 & 22.0 & 34.6 & 75 & 42 & 2.5 \\
\hline 305 & 981.2 & 1183.9 & 26.3 & 43.6 & 83 & 40 & 2 \\
\hline 356 & 967.4 & 1167 & 26.6 & 30.7 & 105 & 39 & 2 \\
\hline Min Target & 862 & 1034 & 18 & 25 & 54 & - & $\begin{array}{l}\text { ASTM \#2 or } \\
\text { finer }\end{array}$ \\
\hline
\end{tabular}




\section{Microstructure}

An etchant containing one percent bromine in methanol was found to be suitable to reveal the microstructure of alloy 945. An optical photomicrograph revealing single phase, twinned, equi- axed microstructure is shown in Figure 7. The age hardening treatment precipitates sub-micron $\mathrm{Ni}_{3}(\mathrm{TiAl})$-type gamma prime and $\mathrm{Ni}_{3}(\mathrm{NbTi})$-type gamma double prime phases, which are responsible for the higher strength, Figure 8.

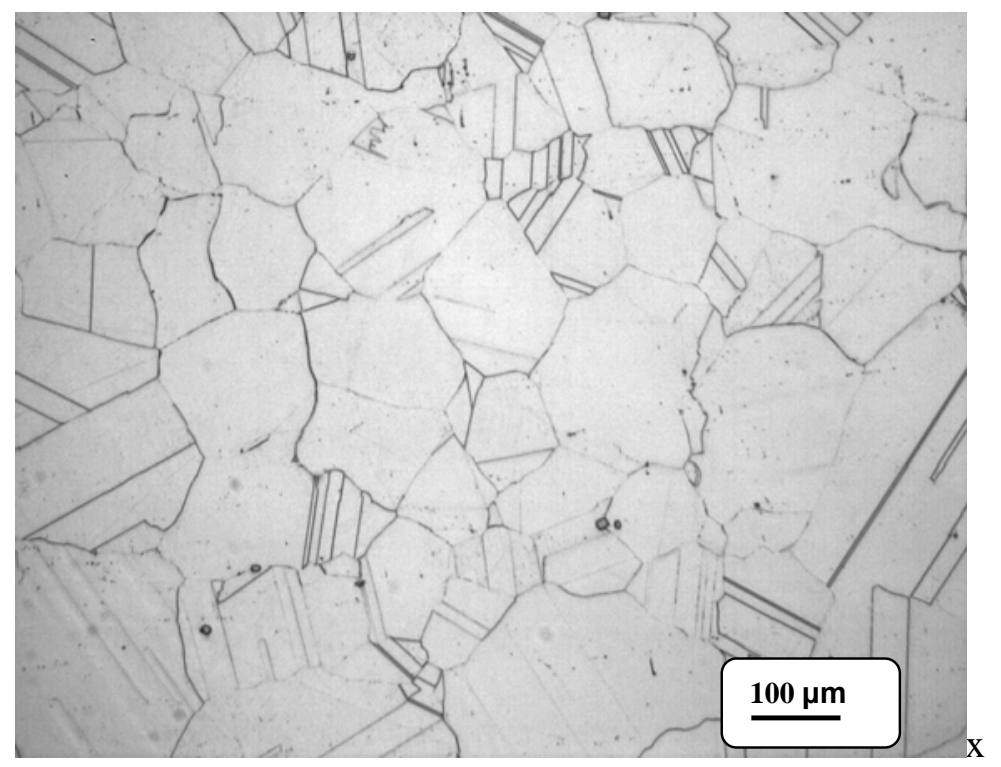

Figure 7. Optical photographs of alloy 945, Magnification $=100 \mathrm{X}$.
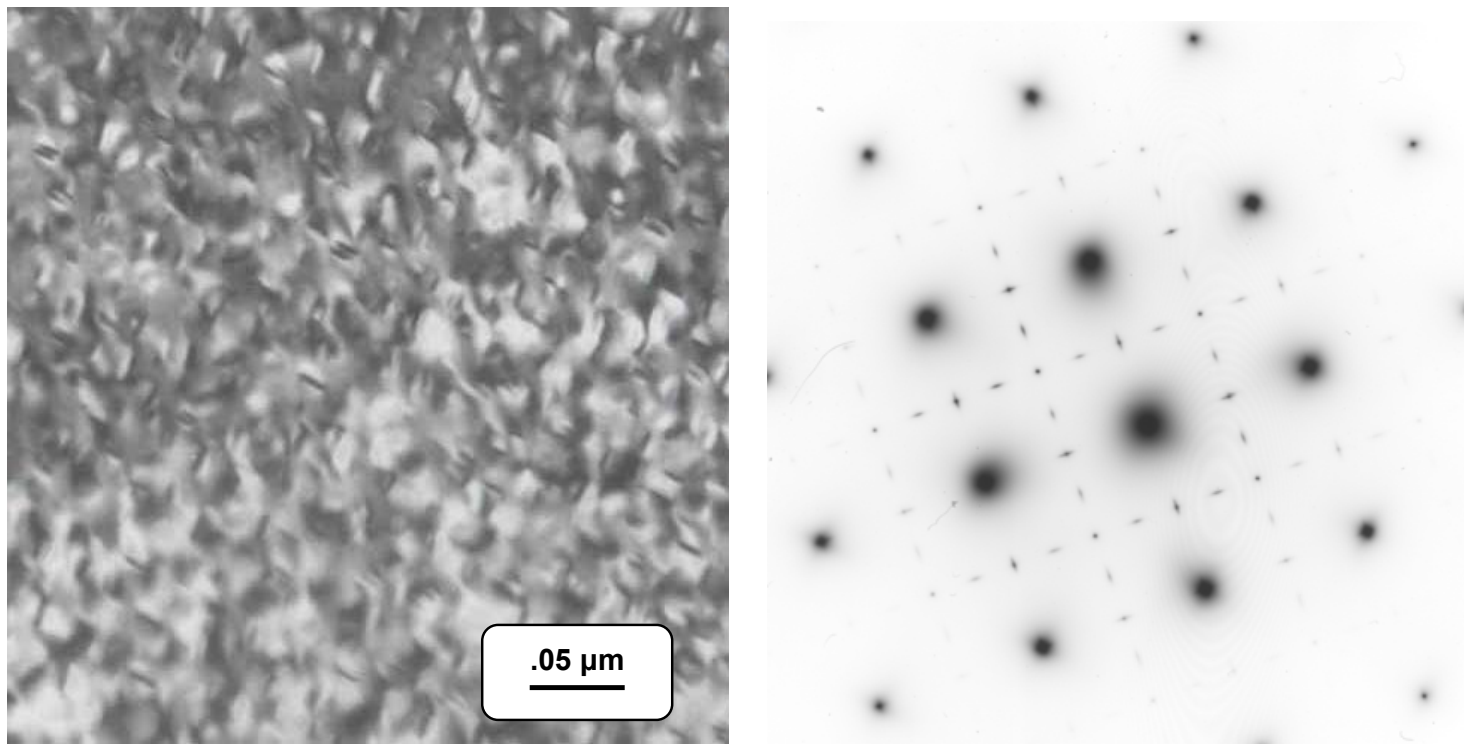

Figure 8. TEM photographs of alloy 945. The left shows gamma prime and gamma double prime distribution and the right shows selected area diffraction pattern of these phases in [001] zone axis. 


\section{Corrosion Resistance}

Stress Corrosion Cracking (SCC):

Corrosion testing in MR0175 / ISO 15156-3 [12] NACE

(National Association of Corrosion Engineers) level V and level VI was carried out on triplicate C-ring specimens for 90 days on three mill heats at $100 \%$ of actual yield strength. Testing was done in accordance with NACE TM0177-2004, method C - C Ring tests.

In these tests, stressed C-ring specimens were enclosed in a pressurized autoclave under specified partial pressure of gasses. The specimens were immersed in a solution containing specified chloride content at a fixed temperature. The tests were run for 90 days and the specimens were examined with 20X magnifier for cracking after the test. No cracking was observed, Tables 5 and 6. Specimen dimensions were: $51 \mathrm{~mm}$ OD, $3.8 \mathrm{~mm}$ wallthickness and $24.1 \mathrm{~mm}$ width. Figure 9 shows a C-ring test specimen.

Table 5. C-ring test results in NACE level V. The environment was $700 \mathrm{kPa} \mathrm{H}_{2} \mathrm{~S}, 700 \mathrm{kPa} \mathrm{CO}, 91000 \mathrm{mg} / \mathrm{l} \mathrm{Cl}$ at $150^{\circ} \mathrm{C}$.

Applied stress was $100 \%$ of room temperature yield strength.

\begin{tabular}{|c|c|c|}
\hline Sample & $\begin{array}{c}\text { Applied } \\
\text { Stress, MPa }\end{array}$ & Results \\
\hline EX0019PY-12 (1) & 920 & No failure, 90 days \\
\hline EX0019PY-12 (2) & 920 & No failure, 90 days \\
\hline EX0019PY-12 (3) & 920 & No failure, 90 days \\
\hline & & \\
\hline EX0019PY-11 (1) & 925 & No failure, 90 days \\
\hline EX0019PY-11 (2) & 925 & No failure, 90 days \\
\hline EX0019PY-11 (3) & 925 & No failure, 90 days \\
\hline & & \\
\hline EX0021PK-11 (1) & 972 & No failure, 90 days \\
\hline EX0021PK-11 (2) & 972 & No failure, 90 days \\
\hline EX0021PK-11 (3) & 972 & No failure, 90 days \\
\hline
\end{tabular}

Table 6. C-ring test results in NACE level VI. The environment was $3500 \mathrm{kPa} \mathrm{H} \mathrm{H}_{2} \mathrm{~S}, 3500 \mathrm{kPa} \mathrm{CO}, 121300 \mathrm{mg} / \mathrm{l} \mathrm{Cl}$ at $175^{\circ}$. Applied stress was $100 \%$ of room temperature yield strength.

\begin{tabular}{|c|c|c|}
\hline Sample & $\begin{array}{c}\text { Applied Stress, } \\
\text { MPa }\end{array}$ & Results \\
\hline EX0019PY-12 (1) & 920 & $\begin{array}{c}\text { No failure, 90 } \\
\text { days }\end{array}$ \\
\hline EX0019PY-12 (2) & 920 & $\begin{array}{c}\text { No failure, 90 } \\
\text { days }\end{array}$ \\
\hline EX0019PY-12 (3) & 920 & $\begin{array}{c}\text { No failure, 90 } \\
\text { days }\end{array}$ \\
\hline EX0019PY-11 (1) & 925 & $\begin{array}{c}\text { No failure, 90 } \\
\text { days }\end{array}$ \\
\hline EX0019PY-11 (2) & 925 & $\begin{array}{c}\text { No failure, 90 } \\
\text { days }\end{array}$ \\
\hline EX0019PY-11 (3) & 925 & $\begin{array}{c}\text { No failure, 90 } \\
\text { days }\end{array}$ \\
\hline EX0021PK-11 (1) & 972 & $\begin{array}{c}\text { No failure, 90 } \\
\text { days }\end{array}$ \\
\hline EX0021PK-11 (2) & 972 & $\begin{array}{c}\text { No failure, 90 } \\
\text { days }\end{array}$ \\
\hline EX0021PK-11 (3) & 972 & $\begin{array}{c}\text { No failure, 90 } \\
\text { days }\end{array}$ \\
\hline
\end{tabular}

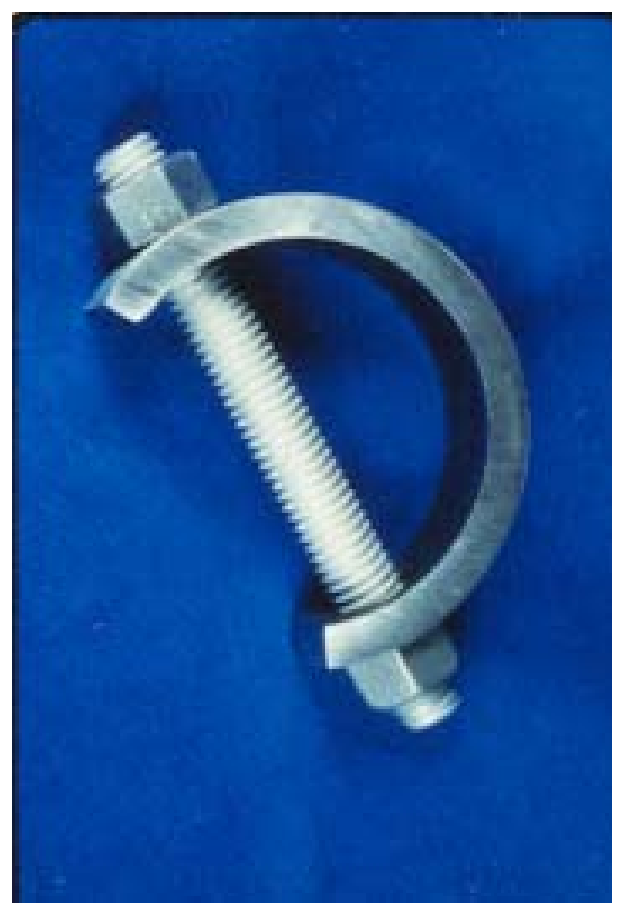

Figure 9. Photograph of a C-ring test specimen. 
Galvanically induced Hydrogen Stress Cracking (GHSC): To fulfill NACE MR0175 / ISO 15156-3: 2003 acceptance procedure, triplicate samples of three heats of alloy 945 were tested for 30 days with $90 \%$ of the actual yield strength in acidified NACE solution A at $24^{\circ} \mathrm{C}$. Testing was carried out in accordance with TM0177 - 2004, method A - Tensile tests. Samples were nominally of diameter $3.8 \mathrm{~mm}$ and gauge length $25.4 \mathrm{~mm}$. The samples were coupled to carbon steel via the stressing bolts. No failures were detected, Table 7.

Table 7. Test results on triplicate samples for GHSC.

\begin{tabular}{|c|c|c|}
\hline Sample & $\begin{array}{c}\text { Applied } \\
\text { Stress, MPa }\end{array}$ & Results \\
\hline EX0019PY-12 (1) & 828 & No failure, 30 days \\
\hline EX0019PY-12 (2) & 828 & No failure, 30 days \\
\hline EX0019PY-12 (3) & 828 & No failure, 30 days \\
\hline & & \\
\hline EX0019PY-11 (1) & 833 & No failure, 30 days \\
\hline EX0019PY-11 (2) & 833 & No failure, 30 days \\
\hline EX0019PY-11 (3) & 833 & No failure, 30 days \\
\hline & & \\
\hline EX0021PK-11 (1) & 875 & No failure, 30 days \\
\hline EX0021PK-11 (2) & 875 & No failure, 30 days \\
\hline EX0021PK-11 (3) & 875 & No failure, 30 days \\
\hline
\end{tabular}

Sulfide Stress Cracking (SSC):

Sulfide stress corrosion cracking testing was done on triplicate samples of three heats in acidified NACE solution A at $24^{\circ} \mathrm{C}$ for 30 days using method A (tensile test) in accordance with TM0177-2004. The samples were stressed to $90 \%$ of the actual yield strength. Samples were nominally of diameter $3.8 \mathrm{~mm}$ and gauge length $25.4 \mathrm{~mm}$. No failures were detected, Table 8 .

Table 8. Test results on triplicate samples for SSC.

\begin{tabular}{|c|c|c|}
\hline Sample & $\begin{array}{c}\text { Applied } \\
\text { Stress, MPa }\end{array}$ & Results \\
\hline EX0019PY-12 (1) & 828 & No failure, 30 days \\
\hline EX0019PY-12 (2) & 828 & No failure, 30 days \\
\hline EX0019PY-12 (3) & 828 & No failure, 30 days \\
\hline & & \\
\hline EX0019PY-11 (1) & 833 & No failure, 30 days \\
\hline EX0019PY-11 (2) & 833 & No failure, 30 days \\
\hline EX0019PY-11 (3) & 833 & No failure, 30 days \\
\hline & & \\
\hline EX0021PK-11 (1) & 875 & No failure, 30 days \\
\hline EX0021PK-11 (2) & 875 & No failure, 30 days \\
\hline EX0021PK-11 (3) & 875 & No failure, 30 days \\
\hline
\end{tabular}

\section{Applications}

Mechanical properties and corrosion resistance of alloy 945 shown in the publication makes it suitable for use in O\&G applications for hangers, packers, valve stems and tubulars used in wellhead, downhole equipments, christmas tree, and side pocket mandrels. Figure 10 shows wellhead used for above ground pressure control.

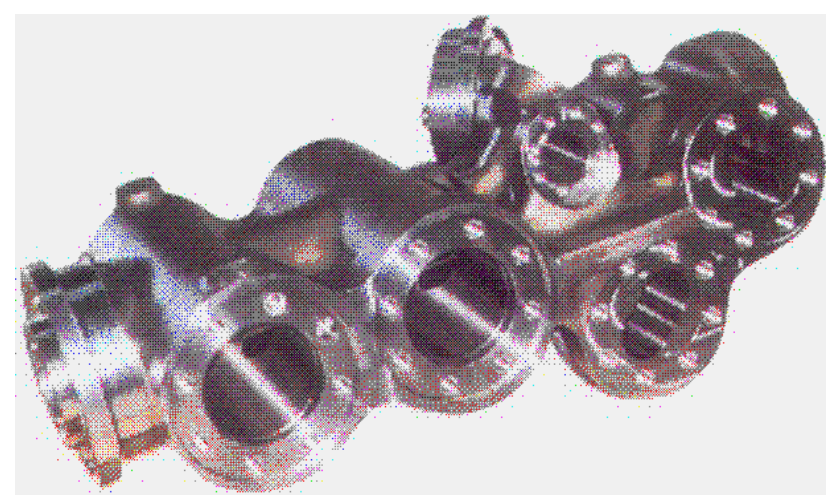

Figure 10. Photograph of a wellhead used for above ground pressure control.

\section{Summary and Conclusion}

A new alloy named INCOLOY* alloy 945 has been developed for O\&G applications using JMatPro simulations and multiple iteration of $22 \mathrm{Kg}$ lab heats. This alloy was scaled up to three 22, 000 to $32,000 \mathrm{Kg}$ mill heats and rolled / forged to $25 \mathrm{~mm}$ $356 \mathrm{~mm}$ diameter rods. Annealed + aged material was tested for mechanical and corrosion properties. The data shows that the material is capable of $860 \mathrm{MPa}$ minimum yield strength with excellent ductility and toughness. The alloy passed complete set of corrosion testing required to qualify for NACE approval as per MR0175 / ISO 15156-3. This included SCC in NACE level VI, GHSC, and SSC corrosion testing.

* INCOLOY is a Trade Mark of Special Metals Corporation 


\section{References}

1. Bruce D. Craig, "Selection guidelines for corrosion resistant alloys in the oil and gas industry”, NiDI Technical Series No 10073, pp. 1-8, July 1995.

2. E. L. Hibner and C. S. Tassen, “Corrosion Resistant OCTG's and Matching Age-Hardenable Bar Products for a Range of Sour Gas Service Conditions”, Corrosion 2001, Paper No 1102, NACE International, Houston, Texas.

3. H. R. Copson, "Effect of Composition on Stress Corrosion Cracking of Some Alloys Containing Nickel”, published in the, Physical Metallurgy of Stress Corrosion Fatigue, Edited by T. Rhodin, pp. 247-269, Interscience Publishers, NY, 1959.

4. R. C. Scarberry, D. L. Graver, and C. D. Stephens, “Alloying for Corrosion Control”, Materials Protection, Vol. 6, No. 6, pp. 54-57, 1967.

5. S. T. Wlodek, Long Term Stability of High Temperature Materials, Edited by G. E. Fuchs, K. A. Dannemann, and T. C. Deragon, pp. 1-30, TMS, 1999.

6. J. Montagnon, USA Patent No. 6,004,408, dated Dec 21, 1999.

7. R. F. Decker, "Strengthening Mechanisms in Nickel-Base Superalloys", Presented at Steel Strengthening Mechanisms Symposium, Zurich, Switzerland, May 5-6, 1969.
8. R. B. Bhavsar and E. L. Hibner, "Evaluation of Corrosion Testing Techniques for Selection of Corrosion Resistant Alloys for Sour Gas Service”, Corrosion 1996, Paper No. 59, NACE International, Houston, Texas.

9. S. K Mannan, E. L. Hibner, B. C. Puckett, "Physical Metallurgy of Alloys 718, 725, 725HS, and 925 for Service in Aggressive Corrosive Environments”, Corrosion 2003, Paper No. 3126, NACE International, Houston, Texas..

10. N. Saunders, Z. Guo, A. P. Miodownik, and J-Ph. Schille, "Modeling the Material Properties and Behavior of Ni-and NiFe-Based Superalloys”, Superalloys 718, 625, 706 and Derivatives, Edited by E. A. Loria, TMS, 2005.

11. M. C. Meyers and K. K. Chawala, Mechanical Metallurgy ((Prentice-Hall Inc., Englewood Cliffs, New Jersey, 1984), page 602-603.

12. Petroleum and Natural gas industries - Materials for use in $\mathrm{H}_{2} \mathrm{~S}$-containing environments in oil and gas production, International Standard Part 3, NACE MR0175 / ISO 151563, first Edition, 2003-12-15. 